\title{
An endoplasmic-reticulum-specific apoptotic pathway is involved in prion and amyloid-beta peptides neurotoxicity
}

\author{
Elisabete Ferreiro, Rosa Resende, Rui Costa, Catarina R. Oliveira, and Cláudia M.F. Pereira* \\ Center for Neuroscience and Cell Biology of Coimbra, Institute of Biochemistry, Faculty of Medicine, University of Coimbra, \\ 3004-504 Coimbra, Portugal
}

Received 12 January 2006; revised 5 April 2006; accepted 22 May 2006 Available online 17 July 2006

\begin{abstract}
Prion $(\operatorname{PrP})$ and amyloid- $\beta(\mathrm{A} \beta)$ peptides are involved in the neuronal loss that occurs in Prion disorders (PrD) and Alzheimer's disease (AD), respectively, partially due to $\mathrm{Ca}^{2+}$ dysregulation. Besides, the endoplasmic reticulum (ER) stress has an active role in the neurotoxic mechanisms that lead to these pathologies. Here, we analyzed whether the ER-mediated apoptotic pathway is involved in the toxic effect of synthetic PrP and A $\beta$ peptides. In PrP106-126- and A $\beta$ 1-40-treated cortical neurons, the release of $\mathrm{Ca}^{2+}$ through ER ryanodine (RyR) and inositol 1,4,5-trisphosphate $\left(\mathrm{IP}_{3} \mathrm{R}\right)$ receptors induces $\mathrm{ER}$ stress and leads to increased cytosolic $\mathrm{Ca}^{2+}$ and reactive oxygen species (ROS) levels and subsequently to apoptotic death involving mitochondrial cytochrome $c$ release and caspases activation. These results demonstrate that the early PrP- and $\mathrm{A} \beta$-induced perturbation of $\mathrm{ER} \mathrm{Ca}^{2+}$ homeostasis is a death message that leads to neuronal loss, suggesting that the regulation of $\mathrm{ER} \mathrm{Ca}^{2+}$ levels may be a potential therapeutical target for PrD and AD.

(C) 2006 Elsevier Inc. All rights reserved.
\end{abstract}

Keywords: Prion disorders; Alzheimer's disease; Prion peptide; Amyloid- $\beta$ peptide; Apoptosis; $\mathrm{Ca}^{2+}$ homeostasis; Endoplasmic reticulum; Oxidative stress

\section{Introduction}

Prion disorders (PrD) and Alzheimer's disease (AD) are progressive neurodegenerative diseases characterized by neuronal loss, cognitive dysfunction and dementia. These diseases are linked by the extracellular deposition of the scrapie isoform of prion protein $\left(\mathrm{PrP}^{\mathrm{Sc}}\right)$ and the amyloid-beta protein $(\mathrm{A} \beta)$, respectively

Abbreviations: A $\beta$, amyloid-beta peptide; PrP, prion peptide; $\mathrm{AD}$, Alzheimer's disease; ER, endoplasmic reticulum; GRP78, glucose-regulated protein 78; Indo-1/AM, Indo-1 acetoxymethyl ester; $\mathrm{IP}_{3} \mathrm{R}$, inositol 1,4,5triphosphate receptor; PrD, Prion disorders; ROS, reactive oxygen species; RyR, ryanodine receptor.

* Corresponding author. Fax: +351 239822776.

E-mail address: cpereira@cnc.cj.uc.pt (C.M.F. Pereira).

Available online on ScienceDirect (www.sciencedirect.com).
(Prusiner, 1996; Wisniewski et al., 1997). In $\operatorname{PrD}$, the $\operatorname{PrP}^{\mathrm{Sc}}$ results from the conversion of the normal protein $\mathrm{PrP}^{\mathrm{C}}$, is insoluble in nondenaturating detergents, aggregates easily and is partially resistant to protease digestion. The PrP106-126, a synthetic peptide homologous to $\mathrm{PrP}^{\mathrm{Sc}}$, has been used as a model system to study prion-induced neurodegeneration (Della-Bianca et al., 2001; Pérez et al., 2003). PrP106-126 is rich in $\beta$-sheet structure, forms aggregates that are detergent-insoluble and PK-resistant and catalyzes the aggregation of endogenous $\operatorname{PrP}^{\mathrm{C}}$ to an amyloidogenic form that shares several characteristics with $\mathrm{PrP}^{\mathrm{Sc}}$ (Ettaiche et al., 2000; Brown, 2000; Singh et al., 2000). In AD, the amyloidogenic material is composed of amyloid-beta peptide $(A \beta)$, derived from $\beta$ - and $\gamma$-secretases cleavage of amyloid precursor protein (APP) in the endoplasmic reticulum (ER), the Golgi apparatus or the endosomal-lysosomal pathway, and most is normally secreted as a 1-40 (A $\beta 1-40)$ or 1-42 (A $\beta 1-42)$ amino acid peptide (Perez et al., 1999). Synthetic $A \beta 1-40$ and $A \beta 1-42$ are amyloidogenic and neurotoxic peptides that have been widely used to mimic in vitro the degenerative process that occurs in the brain of $\mathrm{AD}$ patients (Mattson, 1997; Pereira et al., 1999).

The ER is an essential intracellular organelle involved in intracellular calcium homeostasis, in folding and processing of proteins and in cell death activation (Baumann and Walz, 2001). $\mathrm{Ca}^{2+}$ release from the ER is mediated through ryanodine receptors $(\mathrm{RyR})$ and inositol 1,4,5-triphosphate receptors $\left(\mathrm{IP}_{3} \mathrm{R}\right)$ (Berridge et al., 2000). Changes in ER $\mathrm{Ca}^{2+}$ homeostasis induce the accumulation of unfolded proteins and activate the ER-stress-induced apoptosis pathway (Kaufman, 1999; Pashen, 2001). In response to ER stress, expression of glucose-regulated protein (GRP) 78, an ER chaperone, is induced (Kaufman, 1999; Rao et al., 2002). Furthermore, caspase-12, that is mainly located on the cytoplasmic side of the ER, is activated (Nakagawa et al., 2000; Nakagawa and Yuan, 2000) and can further activate caspase-9 and -3 (Morishima et al., 2002).

It was recently shown that caspase-12 knock-out mice are resistant to ER stress and to death caused by $A \beta$ protein (Nakagawa et al., 2000) and also that caspase-12 activation and increased expression of GRP58, a chaperone with (PDI)-like activity, occur in cells treated with $\operatorname{PrP}^{\mathrm{Sc}}$ (Hetz et al., 2003, 2005). These results 
strongly support that ER stress is involved in the neuronal death that occurs in PrD and AD. In vitro studies have suggested that ER $\mathrm{Ca}^{2+}$ dyshomeostasis and oxidative stress are synergistically related. While ER function is sensitive to the presence of oxidants (Dreher et al., 1995; Racay et al., 1995; Viner et al., 1996; Hayashi et al., 2005), reactive oxygen species (ROS) can also be produced intracellularly from the stress-regulated release of calcium from the ER. This calcium is readily taken up by mitochondria, resulting in the elevation of ROS (Tardif et al., 2005).

The purpose of the present study was to elucidate the role of ER-mediated apoptotic pathway in the neurotoxic effects induced by PrP106-126 and A $\beta 1-40$. Our results suggest that, in ER, the early $\mathrm{Ca}^{2+}$ release through the RyR and $\mathrm{IP}_{3} \mathrm{R}$, induced by these peptides, is involved in the perturbation of $\mathrm{Ca}^{2+}$ homeostasis and ROS production, leading to cytochrome $c$ release and caspase-3 activation and finally to apoptotic cell death. These findings give a contribution to the elucidation of the mechanism of neuronal death that occurs in PrD and AD.

\section{Materials and methods}

\section{Materials}

Neurobasal medium and B27 supplement were purchased from Gibco BRL, Life Technologies (Scotland, UK). Trypsin, deoxyribonuclease I (DNase I), trypsin inhibitor type II-S-soybean, protease inhibitors, phenylmethylsulfonyl fluoride (PMSF), bovine serum albumin (BSA), dantrolene and thapsigargin were obtained from Sigma Chemical Co. (St. Louis, MO, USA). SYTO-13, propidium iodide (PI), Indo-1 acetoxymethyl ester (Indo-1/AM), 2',7'-dichlorodihydrofluorescein diacetate $\left(\mathrm{DCFH}_{2}\right.$-DA), MitoTracker Green, Hoechst 33342 and Alexa Fluor 594 goat antimouse IgG conjugate were purchased from Molecular Probes (Leiden, Netherlands). The synthetic A $\beta 1-40$, A $\beta 40-1$, PrP106126 and PrPscrambled peptides were from Bachem (Bubendorf, Switzerland). Ionomycin and xestospongin $\mathrm{C}$ were purchased from Calbiochem (Darmstadt, Germany). The colorimetric substrates for caspase-2 [N-acetyl-Val-Asp-Val-Ala-Asp- $P$-nitroanilide (AcVDVAD-pNA)], caspase-6 [ $N$-acetyl-Val-Glu-Ile-Asp- $P$-nitroanilide (Ac-VEID-pNA)] and caspase-9 [ $N$-acetyl-Leu-Glu-His-Asp$P$-nitroanilide (Ac-LEHD-pNA)] were obtained from BioSource International (Nivelles, Belgium), whereas the substrate for caspase-3 [ $N$-acetyl-Asp-Glu-Val-Asp- $P$-nitroanilide (DEVDpNA)] was from Calbiochem (Darmstadt, Germany) and for caspase- 8 [ $N$-acetyl-Ile-Glu-Thr-Asp- $P$-nitroanilide (Ac-IETDpNA)] was from Sigma Chemical Co. (St. Louis, MO, USA). Bio-Rad protein dye assay, reagents and apparatus used in immunoblotting assays were purchased from Bio-Rad (Hercules, CA, USA). The following primary antibodies were from BD Pharmingen (San Diego, CA, USA): monoclonal mouse anti-BiP/ Grp78, monoclonal mouse reactive against the native form of cytochrome $c$ and polyclonal rabbit anti-caspase-12. The monoclonal mouse anti-microtubule-associated protein 2 (MAP2) and the rabbit anti-glial fibrillary acidic protein (GFAP) antibody were purchased from Sigma Chemical Co. (St. Louis, MO, USA). The goat anti-rabbit $\operatorname{IgG}$ and goat anti-mouse $\operatorname{IgG}$ antibodies conjugated to alkaline phosphatase, the enhanced chemiFluorescence reagent $(\mathrm{ECF})$ and the polyvinylidene difluoride (PVDF) membrane were obtained from Amersham Pharmacia Biotech (Buckinghamshire, UK). The DakoCytomation Fluorescent mounting medium was purchased from DakoCytomation (Carpinteria,
California, USA). All the other chemicals were obtained from Sigma (St. Louis, MO, USA) or from Merck kgaA (Darmstadt, Germany).

\section{Primary cortical neuronal cultures and experimental treatments}

Primary cultures of cortical neurons were prepared from 15 to 16 days embryos of Wistar rats according to the method described by Hertz et al. (1989), with some modifications (Agostinho and Oliveira, 2003). Briefly, removed cortices were dissected and placed in $\mathrm{Ca}^{2+}$ - and $\mathrm{Mg}^{2+}$-free Krebs buffer (in $\mathrm{mM}$ ): $\mathrm{NaCl} 120$, $\mathrm{KCl} 4.8, \mathrm{KH}_{2} \mathrm{PO}_{4}$ 1.2, glucose 13 and HEPES $10(\mathrm{pH} 7.4)$ supplemented with BSA $(0.3 \mathrm{mg} / \mathrm{ml})$. Minced cortical tissues were washed and incubated in Krebs solution supplemented with BSA, and containing trypsin $(0.5 \mathrm{mg} / \mathrm{ml})$ and DNase $\mathrm{I}(0.04 \mathrm{mg} / \mathrm{ml})$, for $10 \mathrm{~min}$ at $37^{\circ} \mathrm{C}$. The digestion was stopped with Krebs buffer containing trypsin inhibitor (type II-S) $(0.75 \mathrm{mg} / \mathrm{ml})$ and DNase I $(0.04 \mathrm{mg} / \mathrm{ml})$ followed by a centrifugation at $140 \times g$ for $5 \mathrm{~min}$. After washing the pellet once with Krebs buffer, the cells were resuspended in fresh Neurobasal medium supplemented with $2 \mathrm{mM}$ L-glutamine, 2\% B27 supplement, penicillin (100 U/ml) and streptomycin $(100 \mu \mathrm{g} / \mathrm{ml})$ and were dissociated mechanically. Cortical cells were plated on poly-L-lysine $(0.1 \mathrm{mg} / \mathrm{ml})$-coated glass coverslips at a density of $0.10 \times 10^{6} \mathrm{cells} / \mathrm{cm}^{2}$ for immunocytochemistry experiments and nuclear morphology studies or $0.40 \times 10^{6}$ cells $/ \mathrm{cm}^{2}$ for measurement of intracellular $\mathrm{Ca}^{2+}$ or ROS levels. For caspase-like activity assays and immunoblotting, neurons were mounted on poly-L-lysine $(0.1 \mathrm{mg} / \mathrm{ml})$-coated dishes at a density of $0.45 \times 10^{6}$ cells $/ \mathrm{cm}^{2}$. The cultures were maintained at $37^{\circ} \mathrm{C}$ in a humidified atmosphere of $5 \% \mathrm{CO}_{2} / 95 \%$ air and were used for experiments after 5 to 7 days in vitro. Differentiated cortical neurons were treated with $A \beta 1-40$ or $A \beta 40$ $1(0.5 \mu \mathrm{M})$ or with PrP106-126 or PrPscrambled $(25 \mu \mathrm{M})$ in serum-free Neurobasal medium supplemented with B27. PrP peptides were added from a stock solution prepared in sterile distilled water, at a concentration of $1 \mathrm{mM}$. A $\beta$ peptides were dissolved in sterile distilled water at a concentration of $6 \mathrm{mg} / \mathrm{ml}$ and diluted to $1 \mathrm{mg} / \mathrm{ml}(231.5 \mu \mathrm{M})$ with phosphate saline buffer (PBS) and then incubated for 5-7 days to induce fibril formation. The concentrations of A $\beta 1-40$ and PrP106-126 used were chosen based on previous results demonstrating that, on cortical neurons, $0.5 \mu \mathrm{M} A \beta 1-40$ and $25 \mu \mathrm{M}$ PrP106-126 induced a maximal toxic effect ( $50 \%$ decrease in cell viability). Before the addition of $A \beta 1-$ 40 or PrP106-126, cells were preincubated for $1 \mathrm{~h}$ with dantrolene $(10 \mu \mathrm{M})$ or xestospongin $\mathrm{C}(1 \mu \mathrm{M})$, concentrations that were shown to exert a maximal protective effect, without being toxic by itself (data not shown).

\section{Assessment of neuronal injury}

After treatment of cortical cells with A $\beta 1-40$ or PrP106-126, neuronal injury was assessed as described in Ferreiro et al. (2004). Reverse A $\beta 1-40$ (A $\beta 40-1)$ or scrambled PrP was also used in order to analyze the specificity of the amino acids sequence of both peptides. Neurons were stained with PI $(2.5 \mu \mathrm{g} / \mathrm{ml})$ and SYTO-13 (3.8 $\mu \mathrm{M})$, and the nuclear morphology was analyzed by fluorescence microscopy. Cortical cells cultured on glass coverslips were treated with A $\beta 1-40$ or PrP106-126, in the absence or in the presence of dantrolene or xestospongin C. Cells were examined and scored with a Nikon Diaphot TMP microscope, using a triple XF-63 Omega filter. All experiments were performed in duplicate, 
and a minimum of 300 cells were scored for each coverslip. The number of viable, necrotic and apoptotic cells was expressed as the percentage $(\%)$ of the total number of cells in the microscope field.

\section{Measurement of intracellular $\mathrm{Ca}^{2+}$ concentration}

Cortical cells cultured on glass coverslips, in the presence or in the absence of peptides, were incubated in the dark with $3 \mu \mathrm{M}$ Indo-1/AM in a salt solution without phosphate containing (in $\mathrm{mM}): \mathrm{NaCl} 132, \mathrm{KCl} 4, \mathrm{CaCl}_{2} 1, \mathrm{MgCl}_{2} 1.4$, glucose 6, HEPES$\mathrm{Na} 10, \mathrm{pH} 7.4$ for $45 \mathrm{~min}$ at $37^{\circ} \mathrm{C}$. The cells were further incubated, for $15 \mathrm{~min}$, in the absence of Indo-1/AM, to ensure a complete hydrolysis of the acetoxymethyl ester of Indo-1. After washing, cells were mounted in a special holder, and the Indo-1 fluorescence was measured with excitation wavelength of $335 \mathrm{~nm}$ and $410 \mathrm{~nm}$ emission. The free intracellular $\mathrm{Ca}^{2+}$ concentration $\left(\left[\mathrm{Ca}^{2+}\right]_{\mathrm{i}}\right)$ was calculated as previously described (Bandeira-Duarte et al., 1990).

\section{Caspases activity assay}

Untreated or treated cortical cells were lysed with a buffer containing (in mM): HEPES-Na 25, $\mathrm{MgCl}_{2} 2$, EDTA 1, EGTA 1 supplemented with $100 \mu \mathrm{M}$ phenylmethylsulphonyl fluoride (PMSF), 2 mM DTT and a protease inhibitor cocktail (containing $1 \mu \mathrm{g} / \mathrm{ml}$ leupeptin, pepstatin A, chymostatin and antipain). The cellular suspension was rapidly frozen/defrosted three times and then centrifuged for $10 \mathrm{~min}$ at $20,200 \times g$. The supernatant was collected and assayed for protein content using the Bio-Rad protein dye assay reagent. To measure caspases activity, aliquots of cell extracts containing $25 \mu \mathrm{g}$ or $40 \mu \mathrm{g}$ of protein were incubated for $2 \mathrm{~h}$ at $37^{\circ} \mathrm{C}$, in a reaction buffer containing $25 \mathrm{mM}$ HEPES-Na, $10 \mathrm{mM}$ DTT, $10 \%$ sucrose and $0.1 \%$ CHAPS (pH 7.4) with $100 \mu \mathrm{M}$ Ac-VDVAD-pNA, Ac-DEVD-pNA, Ac-VEID-pNA, AcIETD-pNA or Ac-LEHD-pNA, chromogenic substrates for caspase-2, -3, -6, -8 and -9, respectively (Cregan et al., 1999). Caspases activity was determined by measuring substrate cleavage at $405 \mathrm{~nm}$ using a microplater reader, and results were expressed as the increase above control absorbance at $405 \mathrm{~nm}$.

\section{Western blotting analysis}

For the preparation of total cell extracts, cells which were either treated or untreated with the peptides were scraped in Neurobasal medium and centrifuged at $140 \times \mathrm{g}$. The pellet was resuspended in $200 \mu \mathrm{l}$ of ice-cold lysis buffer containing (in mM): HEPES-Na 25, $\mathrm{MgCl}_{2}$ 2, EDTA 1, EGTA 1, supplemented with $100 \mu \mathrm{M}$ PMSF, $2 \mathrm{mM}$ DTT and protease inhibitor cocktail (containing $1 \mu \mathrm{g} / \mathrm{ml}$ leupeptin, pepstatin A, chymostatin and antipain). Cell lysates were frozen three times in liquid $\mathrm{N}_{2}$ and were centrifuged at $140 \times g$ to remove nuclei and large debris. Protein concentration in the supernatant was measured using the Bio-Rad protein dye assay reagent. Samples were denaturated at $95^{\circ} \mathrm{C}$ for $3 \mathrm{~min}$ in a $6 \times$ concentrated sample buffer $(\mathrm{mM})$ : Tris 500, DTT 600, $10.3 \%$ SDS, $30 \%$ glycerol and $0.012 \%$ bromophenol blue. Equal amount of each sample of protein was separated by electrophoresis on a $10 \%$ SDS-polyacrylamide gels (SDS-PAGE) and electroblotted onto PVDF membranes. The identification of proteins of interest was facilitated by the usage of a prestained precision protein standard (Bio-Rad) which was run simultaneously. After the proteins were electrophoretically transferred, the membranes were incubated for $1 \mathrm{~h}$ at room temperature (RT) in Tris buffer (mM; $\mathrm{NaCl}$ 150, Tris- $\mathrm{HCl} 25$ (pH 7.6) with $0.1 \%$ Tween 20 (TBS-T) containing $5 \%$ nonfat dry milk) to eliminate nonspecific binding, and were next incubated overnight at $4^{\circ} \mathrm{C}$ in TBS-T containing $1 \%$ nonfat dry milk with a rabbit polyclonal primary antibody against caspase-12 (1:1000 dilution) or a mouse monoclonal primary antibody against GRP78 (1:250 dilution). The membranes were washed several times and then incubated in TBS-T with $1 \%$ nonfat dry milk for $2 \mathrm{~h}$ at RT, with the appropriate alkaline-phosphatase-conjugated anti-rabbit or anti-mouse secondary antibody at a dilution of 1:25,000 or 1:20,000, respectively. Immunoreactive bands were detected after incubation of membranes with ECF reagent for 5-10 min, on a Bio-Rad Versa Doc 3000 Imaging System.

\section{Immunocytochemistry}

Control, A $\beta 1-40$ - or PrP106-126-treated cells were washed two times in PBS buffer ( $\mathrm{pH} 7.4$ ) and were fixed with $4 \%$ paraformaldehyde for $30 \mathrm{~min}$ at RT. For cytochrome $c$ release experiments, cells were incubated with $750 \mathrm{nM}$ MitoTracker Green for $45 \mathrm{~min}$ at $37^{\circ} \mathrm{C}$, in the dark. Then, the cells were permeabilized for 2 min at RT with $0.2 \%$ Triton-X100 in PBS buffer (pH 7.4), and the nonspecific binding sites were blocked for $30 \mathrm{~min}$ at RT in PBS containing 3\% BSA. Cells were incubated for $1 \mathrm{~h}$ with a mouse monoclonal anti-cyt $c$ antibody that recognizes the native form of the protein (1:100 dilution), or with a mouse monoclonal antiMAP2 (1:500 dilution) and a rabbit monoclonal anti-GFAP antibody (1:200 dilution), prepared in PBS containing $3 \%$ of BSA and incubated with Alexa Fluor 594 goat anti-mouse IgG antibody conjugated (1:100 dilution in $3 \% \mathrm{BSA} / \mathrm{PBS})$ or with Alexa Fluor 488 goat anti-rabbit IgG antibody conjugated (1:100 dilution in $3 \% \mathrm{BSA} / \mathrm{PBS}$ ) for $1 \mathrm{~h}$ at RT. Cells labeled with antiMAP2 and anti-GFAP were also incubated with Hoechst 33342 (15 $\mu \mathrm{g} / \mathrm{ml}$ dilution in PBS). Finally, the cells were washed and treated with DakoCytomation Fluorescent mounting solution on a microscope slide, and neurons were visualized in a confocal microscope (Bio-Rad MRC 600, Cambridge, MA, UK) or in an Axiovert 200 fluorescence microscope (Zeiss, Germany).

\section{Measurement of intracellular reactive oxygen species}

The levels of ROS, in particular of intracellular hydroperoxides, were assessed using the oxidant-sensitive dye 2',7'-dichlorodihydrofluorescin diacetate $\left(\mathrm{DCFH}_{2}-\mathrm{DA}\right)$, a cell-permeant nonfluorescent compound that is converted to the acid $2^{\prime}, 7^{\prime}$ dichlorodihydrofluorescin $\left(\mathrm{DCFH}_{2}\right)$ when the acetate groups are removed by intracellular esterases. This ionized acid is trapped into the cells and can be oxidized to fluorescent 2',7'-dichlorofluorescin (DCF) (Cathcart et al., 1993). Control cells treated with A $\beta 1-40$ or

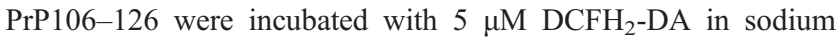
medium for $20 \mathrm{~min}$ at $37^{\circ} \mathrm{C}$. After $\mathrm{DCFH}_{2}-\mathrm{DA}$ incubation, cells were washed and further incubated in sodium medium for $10 \mathrm{~min}$ to allow its desterification. Then, the glass coverslips containing the loaded cells were mounted in a special holder (Perkin-Elmer L225008) and placed inside a temperature-controlled $\left(37^{\circ} \mathrm{C}\right)$ cuvette containing sodium medium, with an alignment of $60^{\circ}$ to the excitation beam (to minimize the effect of light reflection). The fluorescence signals, corresponding to intracellular ROS, were monitored for $30 \mathrm{~min}$ at $502 \mathrm{~nm}$ excitation and $550 \mathrm{~nm}$ emission, using a temperature-controlled SPEX Fluorolog spectrometer. 


\section{Statistical analysis}

Results are expressed as means \pm SEM of the number of experiments indicated in the figure captions. Statistical significance was performed using an analysis of variance (ANOVA) followed by Dunnett's post hoc tests for multiple comparisons or by the unpaired two-tailed Student's $t$ test. A $P<0.05$ value was considered statistically significant.

\section{Results}

Cortical neurons used throughout this work were cultured in serum-free Neurobasal medium in the presence of B27 supplement, which supports growth of neurons and minimizes glial cell proliferation. The purity of neuronal cultures was confirmed by immunocytochemistry using the neuronal marker microtubuleassociated protein 2 (MAP-2) antibody and the anti-glial fibrillary acidic protein (GFAP) antibody, a marker of astrocytic proliferation (Fig. 1A). Quantification of MAP-2- and GFAP-positive cells demonstrated that, under our experimental conditions, $\sim 94 \%$ of the cells in culture were neurons (Fig. 1B). Therefore, due to the reduced number of astrocytes in the cultures used in this study (less than $10 \%$ ), the effects observed could be attributed solely to neurons.

\section{PrP106-126 and AB1-40 increase the levels of ER stress markers}

To evaluate whether ER stress is induced in cortical neurons by PrP106-126 and A $\beta 1-40$ peptides, the levels of two known ER stress markers, Grp78 and caspase-12 (Rao et al., 2002; Nakagawa and Yuan, 2000), were analyzed by Western blotting. Treatment of cortical neurons with PrP106-126 $(25 \mu \mathrm{M})$ or A $31-40(0.5 \mu \mathrm{M})$ induces a significant increase in Grp78 levels at $6 \mathrm{~h}$ which persists at $24 \mathrm{~h}$ of incubation, when compared with untreated cells (Fig. 2A). Furthermore, the decrease of the pro-caspase-12 levels in treated cortical neurons suggests that PrP106-126 and A $\beta 1-40$ lead to the activation of caspase-12. After exposure of cells to the synthetic peptides, during 6 or $24 \mathrm{~h}$, the pro-caspase-12 levels
A

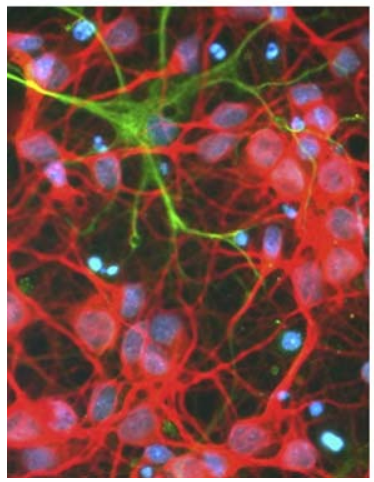

B

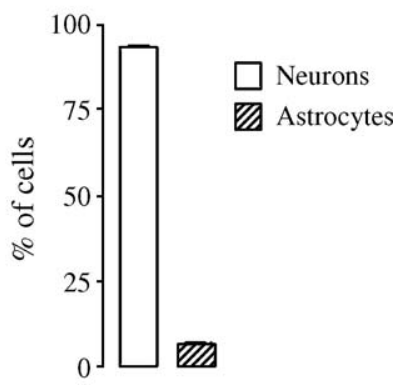

Fig. 1. Relative proportion of neurons and astrocytes in cortical cultures. (A) Representative image of cortical cells labeled with the neuronal marker microtubule-associated protein 2 (MAP-2) antibody (red) and the anti-glial fibrillary acidic protein (GFAP) antibody, a marker of astrocytic proliferation (green). Nucleus was stained with Hoechst 33342 (blue) (magnification $400 \times$ ). (B) Quantification of the relative proportion of neurons and astrocytes. (For interpretation of the references to colour in this figure legend, the reader is referred to the web version of this article.)
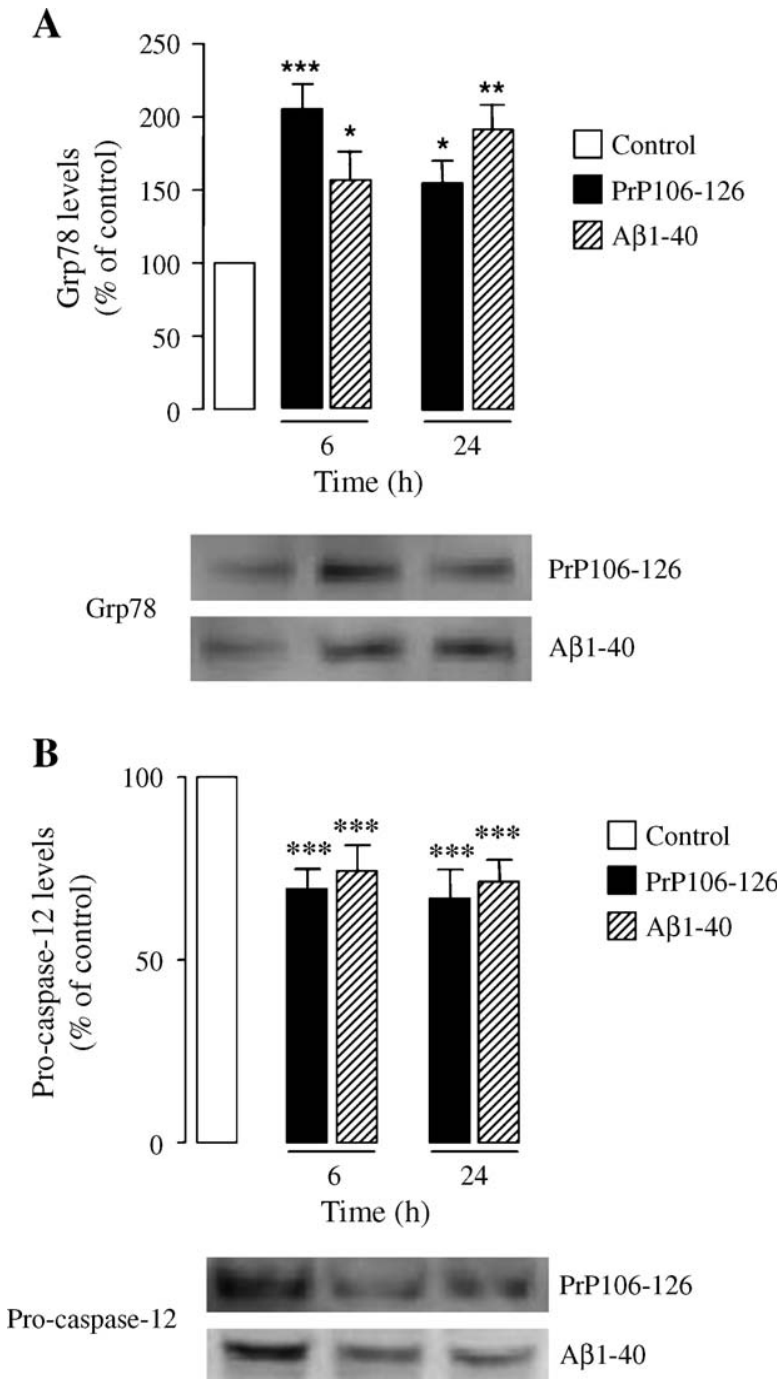

Fig. 2. PrP106-126 and A $\beta 1-40$ induce the increase of Grp78 levels and caspase-12 activation. Total cell extracts were obtained from cortical neurons treated with PrP106-126 $(25 \mu \mathrm{M})$ or $\mathrm{A} \beta 1-40(0.5 \mu \mathrm{M})$, for $6 \mathrm{~h}$ or $24 \mathrm{~h}$, and the levels of Grp78 (A) and pro-caspase-12 (B) were determined by Western blotting. To determine the significance of the differences in expression level, data from at least three different experiments were analyzed by densitometry (Graphs). Data were expressed as the mean \pm SEM. $* P<0.5 ; * * P<0.01 ; * * * P<0.001$ with respect to control values.

decreased significantly (Fig. 2B). These results indicate that PrP106-126 and A $\beta 1-40$ induce ER stress and caspase-12 activation in cortical neurons.

Cortical neurons treated with PrP106-126 and AB1-40 have high intracellular $\mathrm{Ca}^{2+}$ levels. ER $\mathrm{Ca}^{2+}$ release contributes to perturbed $\mathrm{Ca}^{2+}$ homeostasis

ER stress and caspase-12 activation can be mediated by $\mathrm{Ca}^{2+}$ signaling (Ferri and Kroemer, 2000), and therefore we analyzed if under our conditions $\mathrm{Ca}^{2+}$ homeostasis was perturbed. We also analyzed the contribution of $\mathrm{ER} \mathrm{Ca}^{2+}$ release by the determination of intracellular $\mathrm{Ca}^{2+}$ levels in the presence or absence of dantrolene and xestospongin C, inhibitors of RyR 

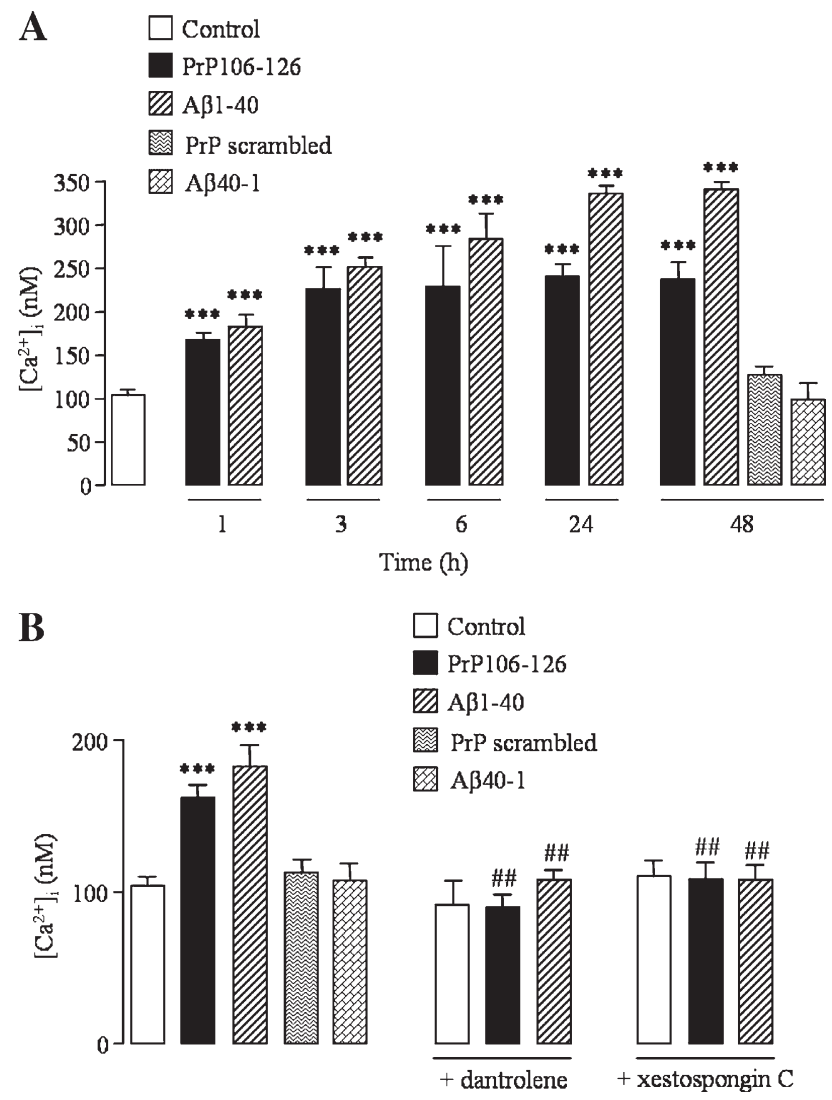

Fig. 3. Effect of PrP106-126 and A $\beta 1-40$ on basal intracellular $\mathrm{Ca}^{2+}$ levels in cortical neurons. (A) Cells were treated with PrP106-126 $(25 \mu \mathrm{M})$ or $\mathrm{A} \beta 1-40(0.5 \mu \mathrm{M})$ for 1 to $48 \mathrm{~h}$. (B) Cortical neurons were incubated with $\operatorname{PrP} 106-126(25 \mu \mathrm{M})$ or $\mathrm{A} \beta 1-40(0.5 \mu \mathrm{M})$ for $1 \mathrm{~h}$, in the absence or in the presence of dantrolene $(10 \mu \mathrm{M})$ or xestospongin $\mathrm{C}(1 \mu \mathrm{M})$. The fluorescence of Indo-1 loaded cells was measured, and the $\left[\mathrm{Ca}^{2+}\right]_{\mathrm{i}}$ was calculated as described in the Materials and methods section. The results are the means \pm SEM of values corresponding at least 3 experiments, each value being the mean of duplicate assays. ${ }^{* * *} P<0.001$ with respect to control values. $\# \# P<0.01$ with respect to $\operatorname{PrP}$ and $\mathrm{A} \beta$ addition.

and $\mathrm{IP}_{3} \mathrm{R}$, respectively. $\operatorname{PrP} 106-126$ and $\mathrm{A} \beta 1-40$ induce a sustained increase of intracellular $\mathrm{Ca}^{2+}$ levels, starting at $1 \mathrm{~h}$ until $48 \mathrm{~h}$ of incubation, when compared with the control (Fig. $3 \mathrm{~A})$. Since PrP106-126 and A $\beta 1-40$ induce a significant increase of intracellular $\mathrm{Ca}^{2+}$ levels at $1 \mathrm{~h}$, we analyzed the contribution of $\mathrm{ER} \mathrm{Ca}^{2+}$ release through $\mathrm{RyR}$ and $\mathrm{IP}_{3} \mathrm{R}$ at this incubation time. When co-incubated with PrP106-126 and A $\beta 1-$ 40 , dantrolene $(10 \mu \mathrm{M})$ or xestospongin $\mathrm{C}(1 \mu \mathrm{M})$ is protective as demonstrated by the decrease in intracellular $\mathrm{Ca}^{2+}$ concentration to values similar to the control (Fig. 3B). Dantrolene and xestospongin $\mathrm{C}$ alone have no effect in intracellular $\mathrm{Ca}^{2+}$ levels of cortical neurons. These results show that PrP106-126 and A $\beta 1-40$ induce an early increase of intracellular $\mathrm{Ca}^{2+}$ levels due to the release of $\mathrm{Ca}^{2+}$ from ER through $\mathrm{RyR}$ and $\mathrm{IP}_{3} \mathrm{R}$, leading to the consequent perturbation of $\mathrm{Ca}^{2+}$ homeostasis. The reverse A $\beta 40-1$ and the scrambled PrP peptides did not lead to any significant increase in the intracellular $\mathrm{Ca}^{2+}$ levels (at 1 and $48 \mathrm{~h}$ ), demonstrating that the specific sequence of amino acids of $\mathrm{A} \beta$ and $\operatorname{PrP}$ peptides is needed for the perturbation of $\mathrm{Ca}^{2+}$ homeostasis (Figs. 3A and B).
PrP106-126 and AB1-40 induce the increase of reactive oxygen species mediated by $\mathrm{ER} \mathrm{Ca}^{2+}$ release

Several studies suggest that, altogether with the changes in calcium dynamics, abnormalities in oxidative stress are central to the toxic effects of PrP106-126 and A $\beta 1-40$ (Gibson, 2002; O'Donavan et al., 2003; Agostinho and Oliveira, 2003). In order to analyze the role of ER $\mathrm{Ca}^{2+}$ release in oxidative stress induced by these amyloidogenic peptides, the production of reactive oxygen species (ROS) was determined. PrP106-126 induces a timedependent increase in intracellular ROS levels that goes from $3 \mathrm{~h}$ to $24 \mathrm{~h}$ of incubation, decreasing at $48 \mathrm{~h}$ (Fig. 4A). At $1 \mathrm{~h}, \mathrm{PrP} 106-$ 126 has no significant effect on intracellular ROS levels. On the
A

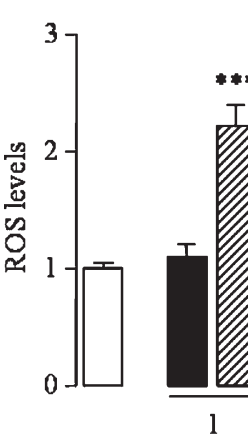

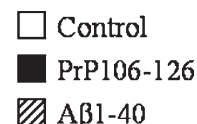

घ $\mathrm{A} 1-40$

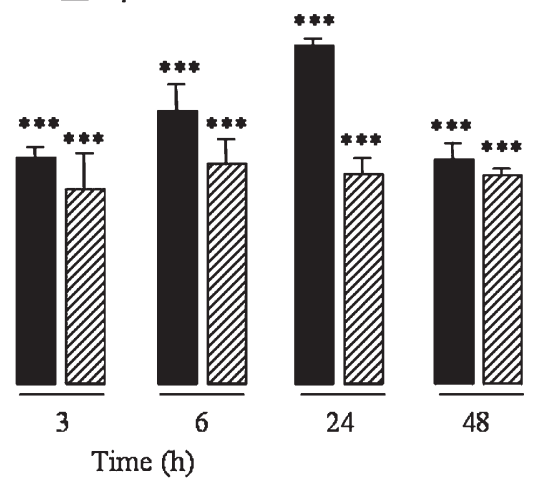

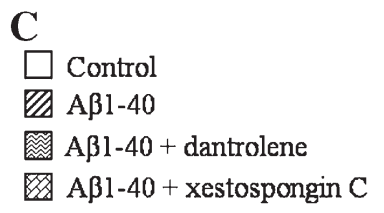

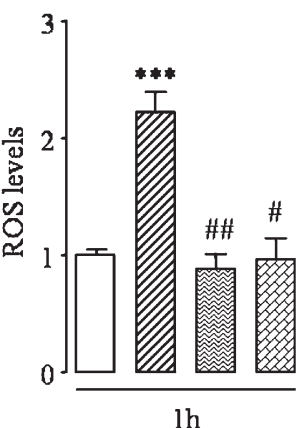

Fig. 4. PrP106-126 and A $\beta 1-40$ induce the increase in intracellular reactive oxygen species (ROS) levels. Dantrolene and xestospongin $\mathrm{C}$ protected against intracellular ROS increase induced by PrP106-126 and A $\beta 1-40$. (A) Cortical neurons were treated with PrP106-126 $(25 \mu \mathrm{M})$ or A $\beta 1-40$ $(0.5 \mu \mathrm{M})$ for 1 to $48 \mathrm{~h}$. (B) Cortical neurons were incubated with PrP106$126(25 \mu \mathrm{M})$ for $3 \mathrm{~h}$, in the absence or in the presence of dantrolene $(10 \mu \mathrm{M})$ or xestospongin $\mathrm{C}(1 \mu \mathrm{M})$. (C) Cortical neurons were incubated with $\mathrm{A} \beta 1-$ $40(0.5 \mu \mathrm{M})$ for $1 \mathrm{~h}$, in the absence or in the presence of dantrolene $(10 \mu \mathrm{M})$ or xestospongin $\mathrm{C}(1 \mu \mathrm{M})$. Intracelullar ROS levels were determined by DCF fluorescence. The results are the means \pm SEM of values corresponding at least 3 experiments, each value being the mean of duplicate assays. $* * * P<0.001$ with respect to control values. $\# P<0.05$; \#\#P<0.01 with respect to $\operatorname{PrP}$ and $A \beta$ addition. 
other hand, A $\beta 1-40$ induces a significant increase of ROS levels at $1 \mathrm{~h}$, maintaining these levels until $48 \mathrm{~h}$ of incubation (Fig. 4A). When cortical cells were treated for $3 \mathrm{~h}$ with PrP106-126 or for $1 \mathrm{~h}$ with $\mathrm{A} \beta 1-40$, in the presence of dantrolene or xestospongin $\mathrm{C}$, a significant decrease in ROS levels is observed, demonstrating that RyR- and $\mathrm{IP}_{3} \mathrm{R}$-mediated ER $\mathrm{Ca}^{2+}$ release is involved in oxidative stress triggered by $\operatorname{PrP}$ and $\mathrm{A} \beta$ peptides in cortical neurons (Figs. 4B and C). Dantrolene or xestospongin C per se did not affect intracellular ROS levels (data not shown).

PrP106-126 and AB1-40 induce cytochrome c release and caspase-2, $-3,-6,-8$ and -9 activation upon $\mathrm{ER} \mathrm{Ca}^{2+}$ release

The release of cytochrome $c$ from mitochondria in cortical neurons treated with PrP106-126 or A $\beta 1-40$ was analyzed by confocal microscopy determining the co-localization of the mitochondrial fluorescent marker MitoTracker Green and an anticytochrome $c$ antibody. The involvement of ER $\mathrm{Ca}^{2+}$ release was evaluated co-treating cells with $\operatorname{PrP}$ or $\mathrm{A} \beta$ peptides and the ER $\mathrm{Ca}^{2+}$ channels inhibitors dantrolene and xestospongin $\mathrm{C}$. After $6 \mathrm{~h}$ of treatment with $\operatorname{PrP} 106-126$ and A $\beta 1-40$, a reduction in the overlay of MitoTracker Green and anti-cytochrome $c$ fluorescence is

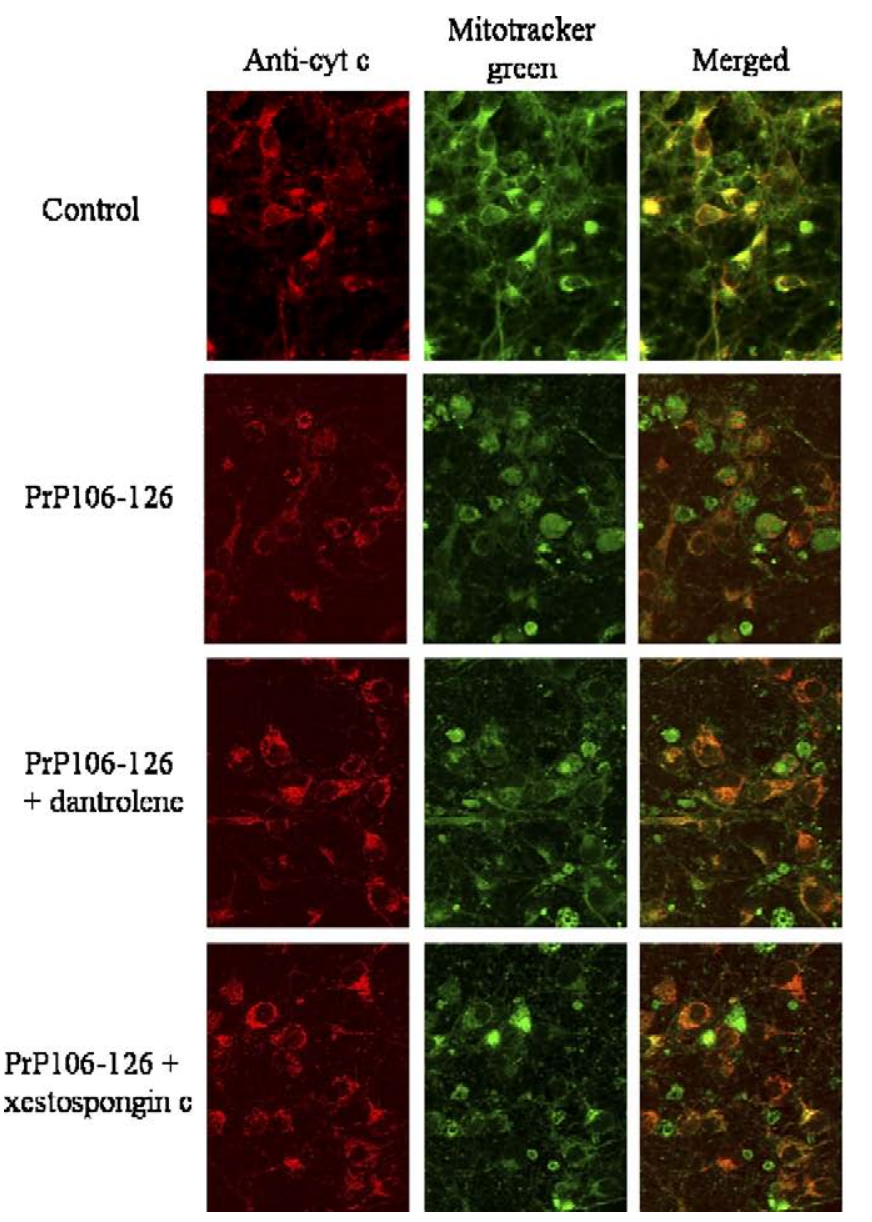

observed when compared with the control (Fig. 5). When cells treated with $\operatorname{PrP}$ and $\mathrm{A} \beta$ were preincubated with dantrolene or xestospongin $\mathrm{C}$, the co-localization of cytochrome $c$ with the mitochondria was observed, as in the control cells, suggesting the involvement of $\mathrm{ER} \mathrm{Ca}^{2+}$ in cytochrome $c$ release from mitochondria induced by both peptides. Similar results were obtained in cells treated with PrP106-126 and A $\beta 1-40$ for $24 \mathrm{~h}$ (data not shown).

Cytochrome $c$ release from the intermembrane space of mitochondria is one of the triggers of the activation of several caspases and apoptosis (Desagher and Martinou, 2000). Therefore, we determined the activity of caspase- $2,-3,-6,-8$ and -9 upon PrP106-126 or A $\beta 1-40$ treatment. In cortical cells incubated with PrP106-126 and A $\beta 1-40$ for $48 \mathrm{~h}$, the activation of caspase-2, -3 , $-6,-8$ and -9 was demonstrated, the most significant increase being observed for caspase-6 (Fig. 6A).

Because caspase- 3 is a key executioner of apoptosis (Kilic et al., 2002), the protective effect of dantrolene and xestospongin $C$ against PrP- and A $\beta$-induced caspase- 3 activation was analyzed. As shown in Fig. 6B, when cortical cells are preincubated with the $\mathrm{Ca}^{2+}$ channel inhibitors dantrolene or xestospongin C, before PrP106126 treatment, the caspase- 3 activation induced by the PrP peptide is significantly reduced. Similar results were obtained in cells treated

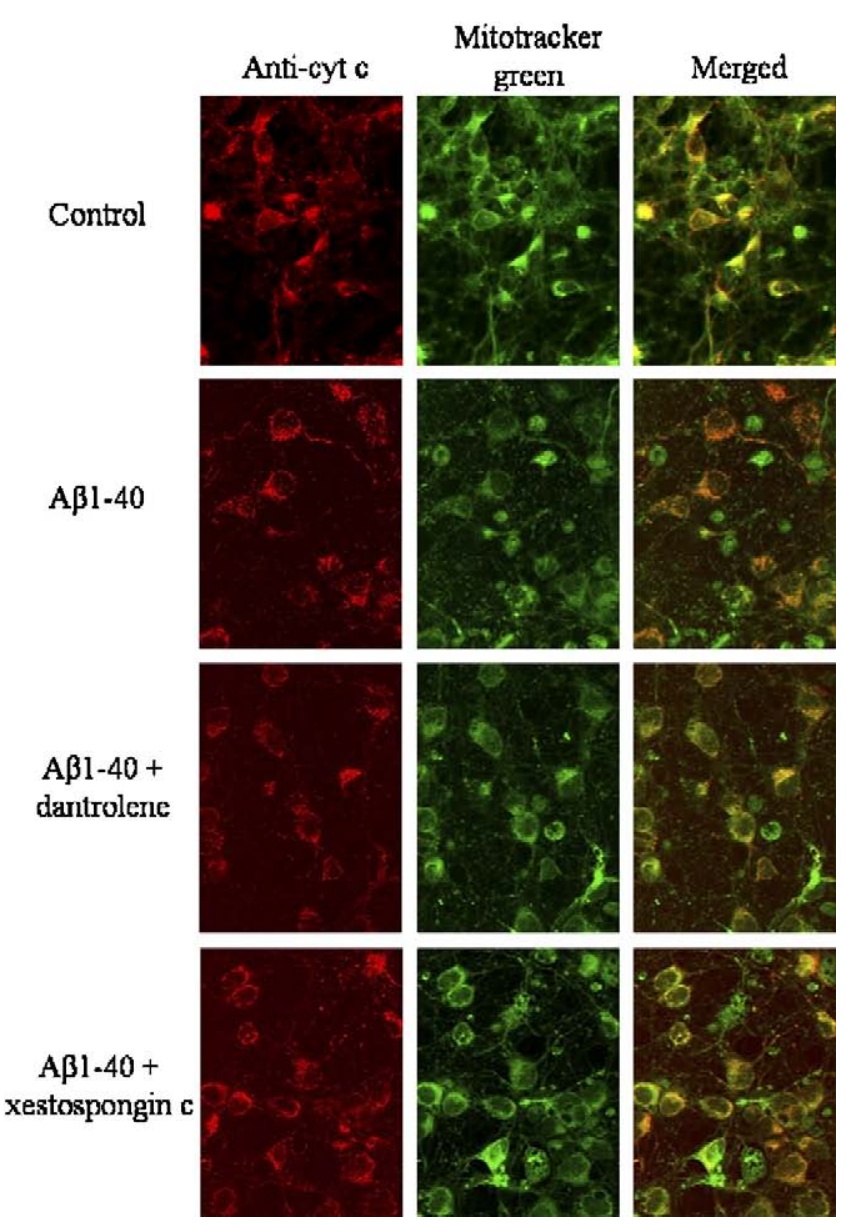

Fig. 5. PrP106-126 and A $31-40$ induce cytochrome $c$ release from mitochondria. $\mathrm{Ca}^{2+}$ release through RyR and IP3R is involved in cytochrome $c$ release induce by $\operatorname{PrP}$ and $A \beta$ peptides. Cortical neurons were treated for $6 \mathrm{~h}$ with PrP106-126 $(25 \mu \mathrm{M})$ or A $\beta 1-40(0.5 \mu \mathrm{M})$, in the absence or the presence of dantrolene $(10 \mu \mathrm{M})$ or xestospongin $\mathrm{C}(1 \mu \mathrm{M})$. Cytochrome $c$ localization was evaluated by immunocytochemistry, using a confocal microscope. Cells were colabeled with anti-cyt $c$ and MitoTracker green. Merged images provide evidence about the co-localization of cyt $c$ immunoreactivity with mitochondria. Overlay of fluorescence (yellow-orange) indicates retention of cyt $c$ in mitochondria. (For interpretation of the references to colour in this figure legend, the reader is referred to the web version of this article.) 
with $A \beta 1-40$ and preincubated with dantrolene or xestospongin $C$. Treatment of cortical cells with dantrolene or xestospongin $C$ for $48 \mathrm{~h}$ did not significantly affect the caspase-3-like activity (Fig. 6B).

Blockage of $\mathrm{ER} \mathrm{Ca}^{2+}$ release protects against PrP106-126- and AB1-40-induced increase in the number of apoptotic cells

In cortical neurons, apoptotic cell death upon exposure to $\mathrm{PrP}$ and $\mathrm{A} \beta$ peptides was analyzed by fluorescence microscopy after SYTO-13/PI labeling. Fig. 7A depicts that PrP106-126 and A $\beta 1-$ 40 significantly increase the number of apoptotic cells after 24 and $48 \mathrm{~h}$ of incubation. The most prominent effect on apoptotic death, observed $48 \mathrm{~h}$ after addition of $\operatorname{PrP}$ and $\mathrm{A} \beta$ to cortical neurons, was prevented by preincubation with dantrolene and xestospongin $\mathrm{C}$ (Fig. 7B). Dantrolene and xestospongin $\mathrm{C}$ alone did not affect the number of apoptotic cells. Results show that the appearance of neurons with apoptotic morphology, upon exposure to $\operatorname{PrP}$ and $A \beta$
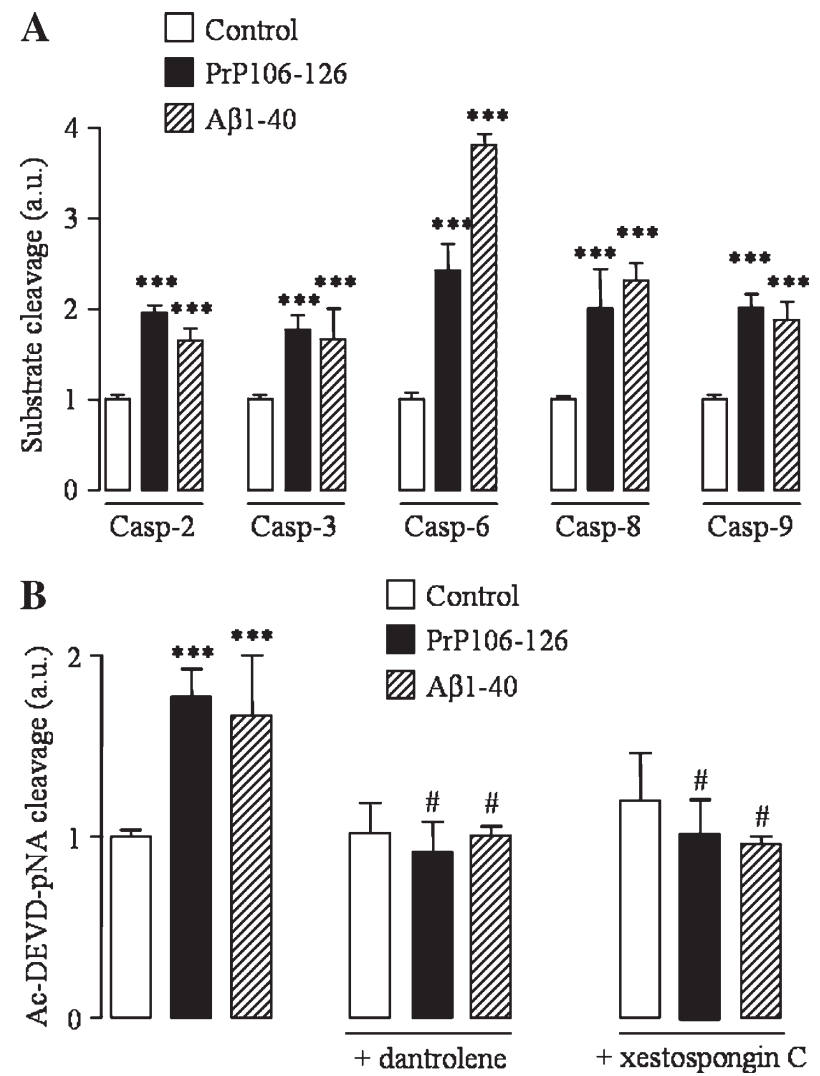

Fig. 6. Caspases activation in cortical neurons induced by PrP106-126 and $A \beta 1-40$. Effect of dantrolene and xestospongin $C$ on the increase of caspase-3-like activity induced by $\operatorname{PrP}$ and $\mathrm{A} \beta$ peptides. (A) Cells were incubated for $48 \mathrm{~h}$ with PrP106-126 $(25 \mu \mathrm{M})$ or A $\beta 1-40(0.5 \mu \mathrm{M})$, and caspase-2, $-3,-6,-8$ and -9 activity was determined. (B) Cells were incubated for $48 \mathrm{~h}$ with PrP106-126 $(25 \mu \mathrm{M})$ or A $\mathrm{A} 1-40(0.5 \mu \mathrm{M})$, in the absence or the presence of dantrolene $(10 \mu \mathrm{M})$ or xestospongin $\mathrm{C}(1 \mu \mathrm{M})$, and caspase- 3 activity was determined. Caspase activity was determined using protein extracts from cortical cells, and the activity measured by the quantity of chromogenic substrates cleavage at $405 \mathrm{~nm}$, as described in the Materials and methods section. The results, expressed as the increase above control values, are the means \pm SEM of values corresponding at least to 3 experiments, each value being the mean of duplicate assays. $* * * P<0.001$ with respect to control values. \#\#\#P<0.05 with respect to $\operatorname{PrP}$ or $\mathrm{A} \beta$ addition.
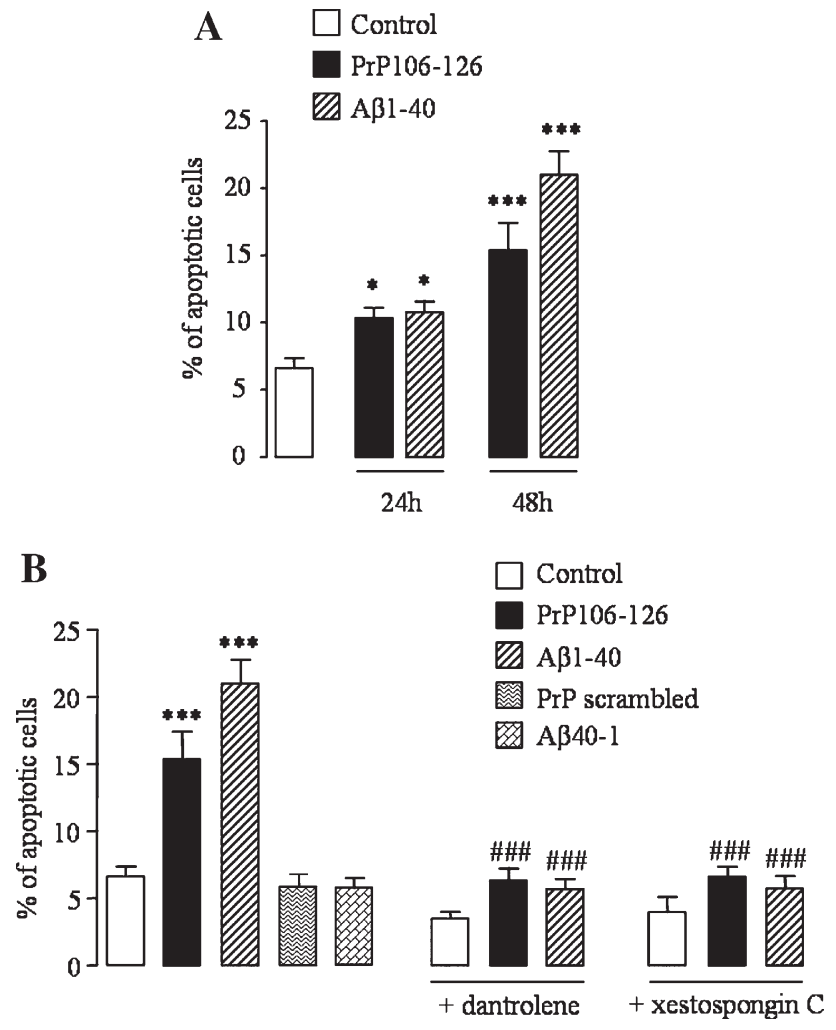

Fig. 7. DNA fragmentation induced by PrP106-126 and A $\beta 1-40$. (A) The number of apoptotic cells induced by $25 \mu \mathrm{M}$ PrP106-126 or $0.5 \mu \mathrm{M} A \beta 1-$ 40 for 24 and $48 \mathrm{~h}$ was determined by SYTO-13 and PI staining, as described in the Materials and methods section. (B) Neurons were incubated with PrP106-126 $(25 \mu \mathrm{M})$ or A $\beta 1-40(0.5 \mu \mathrm{M})$ for $48 \mathrm{~h}$ in the absence or the presence of dantrolene $(10 \mu \mathrm{M})$ or xestospongin $\mathrm{C}(1 \mu \mathrm{M})$. The results, expressed as the percentage of the total number of cells, are the means \pm SEM of values corresponding at least to 3 experiments, each value being the mean of duplicate assays. ${ }^{*} P<0.05$; $* * * P<0.001$ with respect to control values. \#\#\#P<0.001 with respect to $\operatorname{PrP}$ or $A \beta$ addition.

peptides, can be prevented by the inhibition of $\mathrm{Ca}^{2+}$ release through ER channels. The reverse A $\beta 40-1$ and the scrambled PrP peptides were not toxic to cortical neurons (Fig. 7B).

\section{Discussion}

In the present study, we show that treatment of cortical neurons with PrP106-126 or A $\beta 1-40$ induces ER stress. This is accompanied by a significant increase in the $\left[\mathrm{Ca}^{2+}\right]_{\mathrm{i}}$ and in the levels of ROS, cytochrome $c$ release from mitochondria and activation of several caspases including caspase-2, -3, -6, -8 and -9, which culminates in apoptotic cell death. These parameters were shown to be prevented by dantrolene and xestospongin $\mathrm{C}$, inhibitors of the ER $\mathrm{Ca}^{2+}$ release through $\mathrm{RyR}$ and $\mathrm{IP}_{3} \mathrm{R}$, demonstrating that the ER $\mathrm{Ca}^{2+}$ release through $\mathrm{RyR}$ and $\mathrm{IP}_{3} \mathrm{R}$ is involved in PrP- and A $\beta$-induced apoptotic death.

Several studies have shown the involvement of ER stress in neuronal death that occurs in PrD and AD and suggest that PrP and $\mathrm{A} \beta$ peptides play a role in ER-mediated cell injury. In fact, Hetz et al. (2003) refer that caspase-12 activation is detected in cells treated with $\operatorname{PrP}^{\mathrm{Sc}}$ and that GRP58, a chaperone with protein disulfide isomerase (PDI)-like activity, protects cells against $\mathrm{PrP}^{\mathrm{Sc}}$ toxicity and decreases the rate of caspase-12 activation (Hetz et al., 
2005). In addition, Nakagawa et al. (2000) point out that cortical neurons deficient in caspase- 12 are more resistant to $A \beta$ protein neurotoxicity. Furthermore, cells that express presenilin 1 mutants, linked to familial $\mathrm{AD}$, have increased susceptibility to ER stress (Katayama et al., 2004; Imaizumi et al., 2001).

Our results show that PrP106-126 and A $\beta 1-40$ induce the increase of GRP78 levels and caspase-12 activation in cortical neurons, indicating that these peptides induce ER stress, which can be activated by the unfolded protein response (UPR) and by disturbance of $\mathrm{Ca}^{2+}$ homeostasis (Kaufman, 1999). The balance between intracellular $\mathrm{Ca}^{2+}$ levels and the ER $\mathrm{Ca}^{2+}$ content is guaranteed by two different processes: the pumping in the ER by SERCA ATPases and the release by the opening of $\mathrm{IP}_{3} \mathrm{R}$ or RyR $\mathrm{Ca}^{2+}$ release channels (Berridge et al., 2000). These $\mathrm{Ca}^{2+}$ release channels of the ER participate in the signal transduction pathway of apoptosis (Guo et al., 1997; Jayaraman and Marks, 1997; Pan et al., 2000). In agreement with results obtained by other authors using PC12 cells (Guo et al., 1996, 1997), we have recently demonstrated that $\mathrm{Ca}^{2+}$ release from RyR but also from $\mathrm{IP}_{3} \mathrm{R}$ is involved in A $\beta 25-35$ toxicity in cortical neurons (Ferreiro et al., 2004). $\mathrm{IP}_{3}$-mediated $\mathrm{Ca}^{2+}$ release from the $\mathrm{ER}$ was previously demonstrated to trigger apoptosis in response to diverse signals (Distelhorst and Roderick, 2003). It has been shown in our laboratory that $\mathrm{A} \beta 25-35 / 1-40$ and PrP106-126 can induce the increase of cytosolic $\mathrm{Ca}^{2+}$ levels in cortical neurons following $24 \mathrm{~h}$ of incubation (Ferreiro et al., 2004; Agostinho and Oliveira, 2003). In the present study, we show that in cortical neurons treated with PrP106-126 and A $\beta 1-40$ intracellular $\mathrm{Ca}^{2+}$ levels increase before $24 \mathrm{~h}$ of incubation. In fact, at $1 \mathrm{~h}$ of incubation, a significant rise in cytosolic $\mathrm{Ca}^{2+}$ concentration was measured. The $\mathrm{Ca}^{2+}$ release through the RyR and $\mathrm{IP}_{3} \mathrm{R}$ contributes to this early $\left[\mathrm{Ca}^{2+}\right]_{\mathrm{i}}$ increase.

Several studies indicate that, in addition to perturbed $\mathrm{Ca}^{2+}$ homeostasis, oxidative stress also occurs in PrD and AD (reviewed in Brown et al., 1996; Agostinho and Oliveira, 2003; Fernaeus and Land, 2005; Sheehan et al., 1997; Zhu et al., 2004). In fact, the ER is especially vulnerable to oxidative stress since it is one of the cell organelles that produce ROS (Hayashi et al., 2005). Furthermore, oxidative stress may lead to perturbations of the $\mathrm{ER} \mathrm{Ca}^{2+}$ homeostasis because many of the regulatory proteins of $\mathrm{ER} \mathrm{Ca}^{2+}$, such as $\mathrm{IP}_{3} \mathrm{R}$ and RyR, the $\mathrm{Ca}^{2+}$ ATPases and the ER-resident proteins, are sensitive to oxidants (Huang et al., 2004). In addition, $\mathrm{Ca}^{2+}$ that results from the depletion of $\mathrm{ER} \mathrm{Ca}^{2+}$ stores can be taken up by juxtaposed mitochondria, inducing ROS formation (Tardif et al., 2005). Our study demonstrates that PrP106-126 and A $\beta 1-40$ induce ROS formation in cortical neurons, and this effect was prevented by dantrolene and xestospongin $\mathrm{C}$, indicating that $\mathrm{Ca}^{2+}$ release through RyR and $\mathrm{IP}_{3} \mathrm{R}$ is involved in $\mathrm{PrP}$ - and $\mathrm{A} \beta$-induced ROS formation. In the case of PrP106-126, the intracellular $\mathrm{Ca}^{2+}$ increase precedes the ROS formation, indicating that intracellular $\mathrm{Ca}^{2+}$ rise is an early event in $\operatorname{PrP}$ peptide toxicity.

$\mathrm{ER} \mathrm{Ca}^{2+}$ release has been shown to have immediate effects on mitochondrial function, leading to rapid $\mathrm{Ca}^{2+}$ accumulation in mitochondria which promotes cytochrome $c$ release and activation of downstream caspase pathways in cells exposed to proapoptotic agents (Nutt et al., 2002). In the cytosol, cytochrome $c$ binds Apaf1 and dATP to form a complex that activates caspase-9, which can activate the executioner caspase-3 (Desagher and Martinou, 2000). Cytochrome $c$ has been shown to be involved in the neurotoxicity of A $325-35$ and PrP106-126 (Cardoso et al., 2002; Agostinho and Oliveira, 2003). Our results show that, beyond the fact that $A \beta$ and PrP peptides induce cytochrome $c$ release from mitochondria, ER
$\mathrm{Ca}^{2+}$ release through $\mathrm{RyR}$ and $\mathrm{IP}_{3} \mathrm{R}$ is involved in the process, demonstrating that mitochondria and the ER cooperate in the neuronal death induced by $\mathrm{A} \beta$ and $\operatorname{PrP}$ peptides. These results are in agreement with data obtained in cells treated with ER stressors in which ER/mitochondria crosstalk was demonstrated (Häcki et al., 2000; Boya et al., 2002). Although our results demonstrate that ER stress induced by $\operatorname{PrP}$ and $A \beta$ peptides occurs upstream of mitochondrial dysfunction, since cytochrome $c$ release is prevented by dantrolene and xestospongin $\mathrm{C}$, we cannot rule out the possibility that mitochondrial dysfunction could also trigger ER stress, propagating the initial injury. Recently, it was demonstrated that both full-length APP and A $\beta$ accumulate in the mitochondria compartment causing mitochondrial dysfunction (Anandatheerthavarada et al., 2003; Lustbader et al., 2004), which may in turn deregulate ER $\mathrm{Ca}^{2+}$ homeostasis. In fact, inhibition of mitochondrial respiratory chain with rotenone was shown to induce ER stress through the phosphorylation of the key ER stress kinases IRE1 $\alpha$ and PKR-like ER kinase (PERK) (Ryu et al., 2002).

Several caspases have been shown to be involved in ER stress. Hitomi et al. (2003) have shown that activation of caspase-12 indirectly activates cytoplasmic caspase- 3 and activation of this caspase is completely suppressed in cells overexpressing Bcl-2 targeted specifically to the ER (Häcki et al., 2000). Dahmer (2005) has shown that thapsigargin, an activator of ER stress, induces activation of the caspase-2, -3 and -7 . He et al. (2002) had already shown that thapsigargin-mediated perturbation in $\mathrm{Ca}^{2+}$ homeostasis upregulates DR5 (death receptor 5) and TRAIL (tumor necrosis factor-related apoptosis inducing ligand), and this is coupled with caspase- 8 activation and Bid cleavage. In the present study, it was demonstrated that caspase-2, $-3,-6,-8$ and -9 activities are increased upon exposure to PrP106-126 and A $\beta 1-40$. Also under our experimental conditions, the caspase- 3 activity increased upon treatment with $\operatorname{PrP} 106-126$ and A $\beta 1-40$ was prevented by the ER $\mathrm{Ca}^{2+}$ release inhibitors dantrolene and xestospongin $\mathrm{C}$, suggesting that perturbation of $\mathrm{ER} \mathrm{Ca}^{2+}$ homeostasis mediated by $\mathrm{Ca}^{2+}$ release from RyR and $\mathrm{IP}_{3} \mathrm{R}$ is involved in the activation of caspase- 3 induced by the peptides.

One possible site of initiation of apoptosis is the synapse. Perturbed synaptic ER $\mathrm{Ca}^{2+}$ homeostasis promotes activation of apoptotic cascades (Mattson, 2000). Therefore, since PrP and $\mathrm{A} \beta$ peptides are known to be produced and to accumulate in high amounts at the synapses (Gong et al., 2003; Sales et al., 1998; Herms et al., 1999), our results support the view that loss of ER $\mathrm{Ca}^{2+}$ homeostasis induced by the peptides is involved in synaptic dysfunction and loss of dendritic spines, which are early events that occur in PrD and AD (Belichenko et al., 2000; Selkoe, 2002). Furthermore, perturbation of $\mathrm{Ca}^{2+}$ homeostasis induced by these peptides can lead to the activation of several kinases, such as GSK3 and $\mathrm{Cdk} 5$, and to the consequent phosphorylation of the microtubule-associated protein tau, leading to the formation of neurofibrillary tangles (Pérez et al., 2003; Lee et al., 2000; reviewed in Fuentalba et al., 2004). Therefore, the ER stress induced by PrP and A $\beta$ in the early stages of the diseases, in which they are implicated, may be associated with synaptic loss and with the presence of neurofibrillary tangles, central hallmarks of $\mathrm{AD}$ that may be also related to PrD. We then suggest that drugs that stabilize neuronal $\mathrm{Ca}^{2+}$ homeostasis, including dantrolene and xestospongin $\mathrm{C}$ to suppress $\mathrm{Ca}^{2+}$ release from ER, are potential therapeutical targets for $\operatorname{PrD}$ and AD.

Altogether, our in vitro results show that PrP106-126 and A $\beta 1-$ 40 induce $\mathrm{Ca}^{2+}$ homeostasis deregulation, oxidative stress and 
apoptotic cell death by a mechanism that involves the early release of $\mathrm{Ca}^{2+}$ from ER through RyR and $\mathrm{IP}_{3} \mathrm{R}$. Furthermore, the results presented here demonstrate that PrP- and $\mathrm{A} \beta$-induced $\mathrm{Ca}^{2+}$ release from ER leads to mitochondrion-mediated cell death, suggesting that both organelles cooperate in PrP- and A $\beta$-induced apoptosis.

\section{Acknowledgments}

This work was supported by FCT (Portuguese Research Council) project no. POCTI/36101/NSE/2000, Elisabete Ferreiro and Rosa Resende have PhD fellowships from FCT (grant no. SFRH/BD/14108/2003 and SFRH/BD/11005/2002, respectively).

\section{References}

Agostinho, P., Oliveira, C.R., 2003. Involvement of calcineurin in the neurotoxic effects induced by amyloid-beta and prion peptides. Eur. J. Neurosci. 17, 1-8.

Anandatheerthavarada, H.K., Biswas, G., Robin, M., Avadhani, N.G., 2003. Mitochondrial targeting and a novel transmembrane arrest of Alzheimer's amyloid precursor protein impairs mitochondrial function in neuronal cells. J. Cell Biol. 161, 41-54.

Bandeira-Duarte, C., Carvalho, C.A.M., Cragoe, E.J., Carvalho, A.P., 1990. Influence of isolation medium on synaptosomal properties: intracellular $\mathrm{pH}, \mathrm{pCa}$ and $\mathrm{Ca}^{2+}$ uptake. Neurochem. Res. 15, 313-320.

Baumann, O., Walz, B., 2001. Endoplasmic reticulum of animal cells and its organization into structural and functional domains. Int. Rev. Cytol. 205, 149-214.

Belichenko, P.V., Brown, D., Jeffrey, M., Fraser, J.R., 2000. Dendritic and synaptic alterations of hippocampal pyramidal neurones in scrapieinfected mice. Neuropathol. Appl. Neurobiol. 26, 143-149.

Berridge, M.J., Lipp, P., Bootman, M.D., 2000. The versality and universality of calcium signaling. Nat. Rev., Mol. Cell Biol. 1, 11-21.

Boya, P., Cohen, I., Zamzami, N., Vieira, H.L., Kroemer, G., 2002. Endoplasmic reticulum stress-induced cell death requires mitochondrial membrane permeabilization. Cell Death Differ. 9, 465-467.

Brown, D.R., 2000. PrPSc-like prion protein peptide inhibits the function of cellular prion protein. Biochem. J. 352, 511-518.

Brown, D.R., Schmidt, B., Kretzschmar, H.A., 1996. Role of microglia and host prion protein in neurotoxicity of a prion protein fragment. Nature $380,345-347$.

Cardoso, S.M., Swerdlow, R.H., Oliveira, C.R., 2002. Induction of cytochrome $c$-mediated apoptosis by amyloid $\beta \quad 25-35$ requires functional mitochondria. Brain Res. 931, 117-125.

Cathcart, R., Scwiers, E., Ames, B.N., 1993. Detection of picomole levels of hydroperoxides using a fluorescent dichlorofluorescein assay. Annal. Biochem. 134, 111-116.

Cregan, S.P., MacLaurin, J.G., Craig, C.G., Roberstson, G.S., Nicholson, D.W., Park, D.S., Slack, R.S., 1999. Bax-dependent caspase-3 activation is a key determinant in p53-induced apoptosis in neurons. J. Neurosci. 19, 7860-7869.

Dahmer, M.K., 2005. Caspases-2, -3 , and -7 are involved in thapsigargininduced apoptosis of SH-SY5Y neuroblastoma cells. J. Neurosci. Res. 80, 576-583.

Della-Bianca, V., Rossi, F., Armato, U., Dal-Pra, I., Costantini, C., Perini, G., Politi, V., Della Valle, G., 2001. Neurotrophin p75 receptor is involved in neuronal damage by prion peptide-(106-126). J. Biol. Chem. 276, 38929-38933.

Desagher, S., Martinou, J.C., 2000. Mitochondria as the central control point of apoptosis. Trends Cell Biol. 10, 369-377.

Distelhorst, C.W., Roderick, H.L., 2003. Ins $(1,4,5) \mathrm{P}_{3}$-mediated calcium signals and apoptosis: is there a role for Bcl-2? Biochem. Soc. Trans. 31, 958-959.

Dreher, D., Jornot, L., Junod, A.F., 1995. Effects of hypoxantine-xantine oxidase on $\mathrm{Ca}^{2+}$ stores and protein synthesis in human endothelial cells. Circ. Res. 76, 388-395.

Ettaiche, M., Pichot, R., Vincent, J.P., Chabry, J., 2000. In vivo cytotoxicity of the prion protein fragment 106-126. J. Biol. Chem. 275, 36487-36490.

Fernaeus, S., Land, T., 2005. Increased iron-induced oxidative stress and toxicity in scrapie-infected neuroblastoma cells. Neurosci. Lett. 382, 217-220.

Ferreiro, E., Oliveira, C.R., Pereira, C., 2004. Involvement of endoplasmic reticulum $\mathrm{Ca}^{2+}$ release through ryanodine and inositol 1,4,5-triphosphate receptors in the neurotoxic effects induced by the Amyloid- $\beta$ peptide. J. Neurosci. Res. 76, 872-880.

Ferri, K., Kroemer, G., 2000. Organelle-specific initiation of cell death pathway. Nat. Cell Biol. 3, E255-E263.

Fuentalba, R.A., Farias, G., Scheu, J., Bronfman, M., Marzolo, M.P., Inestrosa, N.C., 2004. Signal transduction during amyloid-betapeptide neurotoxicity: role in Alzheimer disease. Brain Res. 47, 257-289.

Gibson, G.E., 2002. Interactions of oxidative stress with cellular calcium dynamics and glucose metabolism in Alzheimer's disease. Free Radical Biol. Med. 32, 1061-1070.

Gong, Y., Chang, L., Viola, K.L., Lacor, P.N., Lambert, M.P., Finch, C.E., Krafft, G.A., Klein, W.L., 2003. Alzheimer's disease-affected brain: presence of oligomeric A beta ligands (ADDLs) suggests a molecular basis for reversible memory loss. Proc. Natl. Acad. Sci. U. S. A. 100, 10417-10422.

Guo, Q., Furukawa, K., Sopher, B.L., Pham, D.G., Xie, J., Robinson, N., Martin, G.M., Mattson, M.P., 1996. Alzheimer's PS-1 mutation perturbs calcium homeostasis and sensitizes PC12 cells to death induced by amyloid $\beta$-peptide. NeuroReport 8, 379-383.

Guo, Q., Sopher, B.L., Furukawa, K., Pham, D.G., Robinson, N., Martin, G.M., Mattson, M.P., 1997. Alzheimer's presenilin mutation sensitizes neural cells to apoptosis induced by trophic factor withdrawal and amyloid beta-peptide: involvement of calcium and oxyradicals. J. Neurosci. 17, 4212-4222.

Häcki, J., Egger, L., Monney, L., Conus, S., Rosse, T., Fellay, I., Borner, C., 2000. Apoptotic crosstalk between the endoplasmatic reticulum and mitochondria controlled by Bcl-2. Oncogene 19, 2286-2295.

Hayashi, T., Saito, A., Okuno, S., Ferrand-Drake, M., Dodd, R.L., Chan, P.H., 2005. Damage to the endoplasmic reticulum and activation of apoptotic machinery by oxidative stress in ischemic neurons. J. Cereb. Blood Flow Metab. 25, 41-53.

He, Q., Lee, D., Rong, R., Yu, M., Luo, X., Klein, M., El-Deiry, W., Huang, Y., Hussain, A., Sheikh, M., 2002. Endoplasmic reticulum calcium pool depletion-induced apoptosis is coupled with activation of the death receptor 5 pathway. Oncogene 21, 2623-2633.

Herms, J., Tings, T., Gall, S., Madlung, A., Giese, A., Siebert, H., Schurmann, P., Windl, O., Brose, N., Kretzschmar, H., 1999. Evidence of presynaptic location and function of the prion protein. J. Neurosci. 19, $8866-8875$

Hertz, E., Yu, A.C.H., Hertz, L., Juurlink, B.H.J., Schousboe, A., 1989. Preparation of primary cultures of mouse cortical neurons. In: Shahar, A., De Vellis, J., Vernadakis, A., Haber, V. (Eds.), A Dissection and Tissue Culture Manual of the Nervous System. Alan R. LissNew York.

Hetz, C., Russelakis-Carneiro, M., Maundrell, K., Castilla, J., Soto, C., 2003. Caspase-12 and endoplasmic reticulum stress mediate neurotoxicity of pathological prion protein. EMBO J. 22, 5435-5445.

Hetz, C., Russelakis-Carneiro, M., Walchli, S., Carboni, S., Vial-Knecht, E., Maundrell, K., Castilla, J., Soto, C., 2005. The disulfide isomerase Grp58 is a protective factor against prion neurotoxicity. J. Neurosci. 25, 2793-2802.

Hitomi, J., Katayama, T., Taniguchi, M., Honda, A., Imaizumi, K., Toyama, M., 2003. Apoptosis induced by endoplasmic reticulum stress depends on activation of caspase- 3 via caspase-12. Neurosci. Lett. 357, 127-130.

Huang, H., Zhang, H., Ou, H., Chen, H., Gibson, G.E., 2004. $\alpha$-Keto- $\beta-$ 
methyl- $n$-valeric acid diminishes reactive oxygen species and alters endoplasmic reticulum $\mathrm{Ca}^{2+}$ stores. Free. Radical Biol. Med. 37, 1779-1789.

Imaizumi, K., Miyoshi, K., Katayama, T., Yoneda, T., Taniguchi, M., Kudo, T., Tohyama, M., 2001. The unfolded protein response and Alzheimer's disease. Biochim. Biophys. Acta 1536, 85-96.

Jayaraman, T., Marks, A.R., 1997. T cells deficient in inositol 1,4,5triphosphate receptor are resistant to apoptosis. Mol. Cell. Biol. 17, 3005-3012.

Katayama, T., Imaizumi, K., Manabe, T., Hitomi, J., Kudo, T., Tohyama, M., 2004. Induction of neuronal death by ER stress in Alzheimer's disease. J. Chem. Neuroanat. 28, 67-78.

Kaufman, R.J., 1999. Stress signaling from the lumen of the endoplasmic reticulum: coordination of gene transcriptional and translational controls. Genes Dev. 13, 1211-1233.

Kilic, M., Schäfer, R., Hoppe, J., Kagerhuber, U., 2002. Formation of noncanonical high molecular weight caspase- 3 and -6 complexes and activation of caspase-12 during serum starvation induced apoptosis in AKR-2B mouse fibroblasts. Cell Death and Differ. 9, 125-137.

Lee, M.S., Kwon, Y.T., Li, M., Peng, J., Friedlander, R.M., Tsai, L.H., 2000. Neurotoxicity induces cleavage of p 35 to p 25 by calpain. Nature 405 , 360-364.

Lustbader, J.W., Cirilli, M., Lin, C., Xu, H.W., Takuma, K., Wang, N., Caspersen, C., Chen, X., Pollak, S., Chaney, M., Trinchese, F., Liu, S., Gunn-Moore, F., Lue, L., Walker, D.G., Kuppusamy, P., Zewier, A.L., Arancio, O., Stern, D., Yan, S.S., Wu, H., 2004. ABAD directly link Ab to mitochondrial toxicity in Alzheimer's disease. Science 304, 448-452.

Mattson, M.P., 1997. Cellular actions of $\beta$-amyloid precursor protein and its soluble and fibrillogenic derivatives. Physiol. Rev. 77, 108-1132.

Mattson, M.P., 2000. Apoptosis in neurodegenerative disorders. Nat. Rev., Mol. Cell Biol. 1, 120-129.

Morishima, N., Nakanishi, K., Takenouchi, H., Takehiko, S., Yasuhiko, Y., 2002. An endoplasmic reticulum stress-specific caspase cascade in apoptosis. J. Biol. Chem. 277, 34287-34294.

Nakagawa, T., Yuan, J., 2000. Cross-talk between two cysteine protease families: activation of caspase-12 by calpain in apoptosis. J. Cell Biol. $150,887-894$.

Nakagawa, T., Zhu, H., Morishima, N., Li, E., Xu, J., Yankner, B.A., Yuan, J., 2000. Caspase-12 mediates endoplasmic-reticulum-specific apoptosis and cytotoxicity by amyloid- $\beta$. Nature $403,98-103$.

Nutt, L.K., Chandra, J., Pataer, A., Fang, B., Roth, J.A., Swisher, G., O’Neil, R.G., McConkey, D.J., 2002. Bax-mediated $\mathrm{Ca}^{2+}$ mobilization promotes cytochrome $c$ release during apoptosis. J. Biol. Chem. 277, 20301-20308.

O’Donavan, C.N., Tobin, D., Cotter, T.G., 2003. Prion protein fragment PrP(106-126) induces apoptosis via mitochondrial disruption in human neuronal SH-SY5Y cells. J. Biol. Chem. 276, 43516-43523.

Pan, Z., Damron, D., Nieminen, A.-L., Bhat, M.B., Ma, J., 2000. Depletion of intracellular $\mathrm{Ca}^{2+}$ by caffeine and ryanodine induces apoptosis of Chinese hamster ovary cells transfected with ryanodine receptor. J. Biol. Chem. 275, 19978-19984.

Pashen, W., 2001. Dependence of vital cell function on endoplasmic reticulum calcium levels: implications for the mechanisms underlying neuronal cell injury in different pathological states. Cell Calcium 29, $1-11$.

Pereira, C., Santos, M.S., Oliveira, C.R., 1999. Involvement of oxidative stress on the impairment of energy metabolism induced by $A \beta$ peptides on PC12 cells: protection by antioxidants. Neurobiol. Dis. 6 , 209-219.

Perez, R.G., Soriano, S., Hayes, J.D., Ostaszewski, B., Xia, W., Selkoe, D.J., Chen, X., Stokin, G.B., Koo, E.H., 1999. Mutagenesis identifies new signals for $\beta$-amyloid precursor protein endocytosis, turnover, and the generation of secreted fragments, including A $\beta 42$. J. Biol. Chem. 274 , 18851-18856.

Pérez, M., Rojo, A.I., Wandosell, F., Díaz-Nido, J., Avila, J., 2003. Prion peptide induces neuronal cell death through a pathway involving glycogen synthase kinase 3. Biochem. J. 372, 126-129.

Prusiner, S.B., 1996. Molecular biology and pathogenesis of prion diseases. Trends Biochem. Sci. 252, 482-487.

Racay, P., Kaplan, P., Lehotsky, J., Mezesova, V., 1995. Rabbit brain endoplasmic reticulum membranes as target for free radicals. Changes in $\mathrm{Ca}^{2+}$-transport and protection by stobadine. Biochem. Mol. Biol. Int. 36, 569-577.

Rao, R.V., Peel, A., Logvinova, A., Del Rio, G., Hermel, E., Yokota, T., Goldsmith, P.C., Ellerby, L.M., Ellerby, H.M., Bredesen, D.E., 2002. Coupling endoplasmic reticulum stress to the cell death program: role of the ER chaperone GRP78. FEBS Lett. 514, 122-128.

Ryu, E.J., Harding, H.P., Angelastro, J.M., Vitolo, O.V., Ron, D., Greene, L.A., 2002. Endoplasmic reticulum stress and the unfolded protein response in cellular models of Parkinson's disease. J. Neurosci. 22, 10690-10698.

Sales, N., Rodolfo, K., Nassig, R., Faucheux, B., Di Giamberardino, L., Moya, K.L., 1998. Cellular prion protein localization in rodent and primate brain. Eur. J. Neurosci. 2464-2471.

Selkoe, D.J., 2002. Alzheimer's disease is a synaptic failure. Science 298, 789-791.

Sheehan, J.P., Swerdlow, R.H., Miller, S.W., Davis, R.E., Parks, J.K., Parker, W.D., Tuttle, J.B., 1997. Calcium homeostasis and reactive oxygen species production in cells transformed by mitochondria from individuals with sporadic Alzheimer's disease. J. Neurosci. 17, 4612-4622.

Singh, N., Gu, Y., Bose, S., Kalepu, S., Mishra, R.S., Verghese, S., 2000. Prion peptide 106-126 as a model for prion replication and neurotoxicity. Front. Biosci. 7, 60-71.

Tardif, K.D., Waris, G., Siddiqui, A., 2005. Hepatitis C virus, ER stress, and oxidative stress. Trends Microbiol. 13, 159-163.

Viner, R.I., Huhmer, A.F.R., Bigelow, D.J., Schoneich, C., 1996. The oxidative inactivation of sarcoplasmic reticulum $\mathrm{Ca}^{2+}$-ATPase by peroxynitrite. Free Radical Res. 24, 243-259.

Wisniewski, T., Ghiso, J., Frangione, B., 1997. Biology of Abeta amyloid in Alzheimer's disease. Neurobiol. Aging 4, 313-328.

Zhu, X., Arun, K.R., Lee, H., Casadesus, G., Smith, M.A., Perry, G., 2004. Oxidative stress signaling in Alzheimer's disease. Brain Res. 1000, 32-39. 